\title{
Distribueret kognition og distribueret sprog: analyse af kognitive events $i$ en akutmedicinsk social praksis
}

\author{
SARAH BRO TRASMUNDI
}

Denne artikels emne falder inden for ny kognitiv sprogforskning, og den diskuterer, hvordan distribueret kognition og distribueret sprog bidrager til studiet af menneskelig interaktion og betydningsdannelse. Artiklen falder $i$ to dele: en teoretisk og en analytisk-empirisk. Første del vurderer og kontrasterer distribueret kognition og distribueret sprog i forhold til klassiske perspektiver på og tilgange til sprog, interaktion og betydningsdannelse (fx samtaleanalyse). Den analytisk-empiriske del præsenterer en analyse af, hvordan funktionelle diagnosticeringsprocesser i læge-patient-interaktioner er betinget af kropslig koordinering med omgivelserne. I forlængelse heraf præsenteres en analysemetode, kognitiv eventanalyse, der netop tager højde for de processer, der udspiller sig i de hurtige interkropslige dynamikker. Med udgangspunkt i autentisk videomateriale har analysen til formål at vise, hvorledes sproglige og kognitive processer udspiller sig i både normative, strukturelle dynamikker såvel som i synkroniserede interkropslige dynamikker, der ikke lader sig beskrive inden for rammerne af mere traditionelle tilgange inden for interaktionsforskningen. Med afsæt i analysen konkluderes det, at konsekvensen af det distribuerede perspektiv ikke kun afspejles på et teoretisk plan. Metodisk er der brug for en analysemetodik, der indfanger sproget som kropslige handlinger. Ydermere har et distribueret perspektiv praktiske implikationer for, hvordan man organiserer og designer omgivelser, hvor der skal træffes beslutninger, og hvordan man uddanner praktikere.

EMNEORD: distribueret kognition, distribueret sprog, interaktion, akutmedicin, kognitiv eventanalyse. 


\section{INTRODUKTION: ET ØKOLOGISK PARADIGME}

Sprogvidenskaben og kognitionsforskningen har de sidste 20-30 år gennemgået en radikal udvikling, der har haft stor betydning for fundamentale og ontologiske diskussioner om, hvad sprog og kognition er, og hvilken rolle disse fænomener har i social interaktion (Steffensen 2011, 2015; Cowley 2007, 2009, 2010, 2011; Love 2004; Pedersen 2012; Thibault 2011). Distribueret sprog og distribueret kognition gør op med princippet om, at sådanne fænomener (sprog og kognition) per se lokaliseres i hjernen eller individet. Et distribueret perspektiv antager nemlig, at sprog og kognition er processer, der må undersøges $i$ den kontekst, de udspiller sig i (Hutchins 1995a, 2014; Cowley 2011). Distribuerede perspektiver på sprog og kognition indskriver sig dermed i den tilgang til sprogbeskrivelse og kognition, der defineres som $ø$ kologisk. Ved en økologisk tilgang forstås, at et fænomen undersøges i sin helhed, også selvom helheden rækker ud over det, der umiddelbart fremtræder for et individ i en her-og-nu-kontekst. Steffensen og Cowley (2010) uddyber, at et fundamentalt ontologisk princip i en sådan tilgang er ikkelokalitet, der udelukker "that states or processes can 'occupy' a determinate space-time zone" (Steffensen og Cowley 2010: 337). I dette perspektiv er det umuligt at lokalisere eller afgrænse sproglige og kognitive processer til fx ord alene eller mentale strukturer i hjernen. Konsekvensen heraf bliver, at også sprog- og kognitionsforskere må studere interaktionsflowet i et system, der rækker ud over det enkelte individ. Derudover ligger der i det økologiske, at ethvert individ er i en direkte relation til dets omgivelser, forstået på den måde, at relationen ikke er medieret af repræsentationer, hvilket vil sige mental processering af symboler, der skaber mentale modeller af virkeligheden, som et individ kan handle på baggrund af (Gibson 1979/86; Steffensen 2013; Cowley 2011).

Efterhånden er perspektiverne "distribueret kognition" og "distribueret sprog" veletablerede og anerkendte inden for deres respektive fagområder og ses ikke længere som et udtryk for en radikal tankegang. Distribueret sprog og distribueret kognition åbner op for nye forklaringsmodeller af, hvordan sprog og kognition relaterer sig til hinanden og ikke mindst, hvordan man metodisk analyserer social interaktion, og hvilke resultater og konklusioner man kan frembringe. 
Denne artikel har to hensigter: (a) at diskutere perspektiverne distribueret sprog og distribueret kognition og $(b)$ at vise, hvordan man undersøger sprog og kognition i praksis med udgangspunkt i disse perspektiver.

Argumentationen i artiklen følger en struktur, hvor de to perspektiver - distribueret kognition og distribueret sprog - diskuteres og kontekstualiseres i forhold til de udfordringer, der følger sådanne antagelser om sprog og kognition. Dernæst anvendes perspektiverne i en analyse af empiriske videodata af akutmedicinske diagnosticeringsprocesser på et dansk hospital. Denne praksis er særlig anvendelig til at illustrere kompleksiteten i sproglige og kognitive processer, da aktørerne ofte er stressede, under tidspres eller mangler informationer for at kunne træffe funktionelle beslutninger, løse problemer og koordinere effektivt. Med andre ord undersøges et økologisk udsnit af den akutmedicinske diagnosticeringspraksis, der involverer patienter, praktikere og den materielle og kulturelle kontekst, de befinder sig i. Sidst diskuterer artiklen de teoretiske, metodiske og praktiske implikationer af analysen.

\section{TEORETISK AFSÆT}

Som led i den følgende historiske indføring i distribueret kognition skitseres først de radikale transformationer, som kognitionsvidenskaben har undergået siden 1960'erne og frem, kort. Retrospektivt er disse transformationer defineret som henholdsvis første-, anden- og tredjegenerationsforløb inden for kognitionsvidenskaben (Steffensen 2012, Steffensen dette nummer).

\subsection{Kognitionsvidenskabens udvikling}

Førstegenerationskognitionsvidenskab knytter sig til perioden fra 1960'erne og op til slutningen af 1970'erne (Steffensen 2012). Perioden prioriterer beregningsmæssige modeller med fokus på hjernens interne manipulation af symbolske repræsentationer og bygger på den antagelse, at kognition er det mentale link mellem perceptuelt input og adfærdsmæssigt output (Boden 2006). Menneskelig kognition anskues i denne generation som en informationsbehandlingsstrategi i analogi 
med måden, hvorpå en computer behandler data (Newell et al. 1958). I slutningen af 1970'erne kunne man med udgangspunkt i fx MR-skanninger demarkere forskellige regioner $i$ hjernen, der i et førstegenerationsperspektiv indeholdt lokal information om kognitive egenskaber som hukommelse og fornuft (Anderson et al. 2012). Kritikere tilkendegav, at sådanne modeller gav indsigter $i$ hjernens modulære opbygning og lokale funktion, men de fremhævede samtidig, at modellerne ikke bidrog tilfredsstillende til forklaringen af kognitive processers funktion uden for laboratoriet og i situationer, hvor mennesket agerer med andre i en kompleks verden (Varela et al. 1999; Anderson et al. 2012; Hutchins 1995a).

Den hjernecentrerede og modulære forstålse af kognition blev derfor i 1970'erne og frem til 1990'erne udfordret af konnektionistiske modeller om kognition. Denne udvikling defineres som andengenerationskognitionsvidenskab og fokuserer på, hvordan kroppen er kognitiv og dermed en del af den kognitive proces (Varela et al. 1991; Lakoff og Johnsson 1999). Modeller og teorier om kropslig kognition banede vejen for fænomenologiske studier inden for kognitionsvidenskaberne. Fx blev Merleau-Pontys kropslige fænomenologi inddraget i og tilpasset studiet af menneskets perceptuelle kapacitet. Dvs. at perception og kognition nu forankres i kroppen og ikke udelukkende i neurale netværk i hjernen: "We encounter the world neither as data-crunching information processors, nor as ghostly apparitions floating over the surface of things like a fog. Perceptual perspective is bodily perspective" (Carman 2008: 11). Studierne af den kognitive proces og lokationen af denne blev kontinuerlig udvidet. Tredjegenerationskognitionsforskningen fremsætter således som et led i denne udvidelse et radikalt opgør med den indre-ydre-dikotomi, der knytter an til andengenerationstilgangens krop-omverden-dualisme. Den nye tradition fik særligt rodfæste i 1990'erne, men kan dateres tilbage til 1980'erne (Hutchins 1995a), og den tager form af 'distribueret kognition', et af de mest centrale perspektiver inden for tredjegenerationskognitionsvidenskaben. Distribueret kognitions opgør med indre-ydre-dikotomien kan ses som et resultat af etnografiske og antropologiske studier af, hvordan mennesker løser komplekse udfordringer i deres daglige arbejde. Én af de centrale bidragsydere til denne forstålse er kognitionsforskeren 
Edwin Hutchins. I november 1980 udførte Hutchins et kognitivt-antropologisk feltstudie på et amerikansk flådeskib, som havde rute i det nordlige Stillehav. På skibets kommandobro kunne han observere navigationsteamets arbejdsprocedurer. Hans observationer førte til radikale hypoteser om kognitionsprocessers ontologiske status (Hutchins 1995a). Resultaterne ledte fokus hen på, hvorledes individuelle handlinger kunne ses som afgørende for teamets koordinerende handlinger, der i sin helhed leder teamet til at træffe koncise beslutninger i forhold til navigation, som intet individ alene kunne komme frem til lige så effektivt og præcist (Hutchins 1995a). I Hutchins skelsættende værk Cognition in the Wild (1995a) argumenterer han for, hvorfor der er behov for at anlægge et andet, og i sin tid radikalt, perspektiv på kognition. Dette nye perspektiv på kognition kalder på undersøgelsesmetoder, der gør forskeren i stand til at studere kognition som en interaktion af mange interagerende elementer $i$ et kognitivt distribueret system.

\subsection{Distribueret kognition}

Distribueret kognition fokuserer på den koordination, der sker i og mellem en agent og dennes omgivelser, og som bidrager til kognitive resultater. Denne koordination defineres med et teknisk begreb som "fleksibel adaptiv adfærd". Dermed bliver det system, der skaber resultater, og dets koordinerende handlinger, identificeret som kognitive (Hollan et al. 2000). Den kognitive proces lokaliseres dermed ikke per se internt i hjernen, men $\mathrm{i}$ et kognitivt system, som rækker ud over individet. Et kognitivt systems grænser defineres funktionelt, hvilket betyder, at specifikke komponenter ( $\mathrm{fx}$ hukommelse, mennesker, fysiske artefakter), der har en afgørende funktion i en kognitiv aktivitet, medregnes i systemet (Hollan et al. 2000). Dvs., at hvis opgaven er at løse et matematikstykke, kunne et tænkt kognitivt system defineres som et system konstitueret af en person, der anvender papir, blyant, hukommelse og medstuderende i den kognitive proces, det er at løse matematikopgaven.

Med distribueret kognition rykker kognitionsforståelsen og kognitionsforskningen ud i den naturalistiske (eller økologiske) verden, hvor individer konfronteres med og håndterer kognitive situationer. Hele situationen, som individet indgår $i$, anses som et potentielt distribueret 
kognitivt system. Giere (2004: 771) definerer et distribueret kognitivt system (herefter DCS) som: "a system that produces cognitive outputs, just as an agricultural system yields agricultural products. The operation of a cognitive system is a cognitive process". Man kan som tidligere nævnt ikke vide a priori, hvilke elementer $\mathrm{i}$ et system der vil bidrage til den kognitive proces, og derfor er analyseobjektet ikke defineret ud fra prædefinerede grænser som fx grænsen mellem krop og hjerne, krop og omverden etc. Hollan et al. (2000: 175) argumenterer:

A process is not cognitive simply because it happens in a brain, nor is a process noncognitive simply because it happens in the interaction among many brains. For example, we have found it productive to consider small sociotechnical systems such as the bridge of a ship [Hutchins, 1995a] or an airline cockpit [Hutchins 1995b; Hutchins and Klausen 1996; Hutchins and Palen 1997] as our unit of analysis. In distributed cognition, one expects to find a system that can dynamically configure itself to bring subsystems into coordination to accomplish various functions. A cognitive process is delimited by the functional relationships among the elements that participate in it, rather than by spatial colocation of elements.

Hollan et al. (2000) understreger på denne måde vigtigheden af at undersøge interaktionssituationer i deres helhed fremfor at beskrive elementer $i$ en proces $i$ isolation ( $f_{x}$ interaktionen mellem en computer og et individ). De oplister tre måder, kognition kan være distribueret på; kognitive processer kan: (a) være distribuerede mellem medlemmer af en social gruppe, $(b)$ involvere koordination af interne og eksterne strukturer (fx materielle, fysiske strukturer i omgivelserne og procedurer), og (c) være distribuerede i tid på en sådan måde, at tidligere situationer og deres produkter får betydning for, hvordan kommende begivenheder udfolder sig (Hollan et al. 2000: 176). I tråd med denne udlægning definerer Goodwin (2000) kognition som en proces, der udspiller sig i situerede aktivitetssystemer, inden for hvilke 'human cognition is embedded not only in biology and linguistic structure, but also history, culture, and the details of local, situated interaction" (Goodwin 2000: 33). I alle tilfælde er pointen, at den kognitive proces udvides og i de fleste situationer involverer langt mere end det enkelte individ. 
Dermed udspiller der sig i tredjegenerationstilgangen et eksplicit opgør med den dualistiske og kartesianske opfattelse af individets mentale og indre tankeproces over for den eksterne kommunikationsproces (Hollan et al. 2000).

Hvor nyere tids kognitionsforskning repræsenterer et opgør med det repræsentationsbaserede perspektiv på kognition (Hutchins 2014; Cowley 2014; Pedersen 2015; Steffensen 2013), ses et tilsvarende opgør i dele af sprogforskningen, nemlig opgøret med sproget som kodeapparat, der antager, at interne repræsentationer oversættes via ydre kommunikative handlinger (Cowley 2011; Love 2004). Denne transformation inden for sprogforskningen har resulteret i perspektiver som $\mathrm{fx}$ distribueret sprog (Cowley 2007, 2009, 2011; Love 2004; Steffensen 2013; Pedersen 2010, 2012, 2015).

\subsection{Distribueret sprog}

I det centrale værk Distributed Language (Cowley 2011) præsenteres forskellige teoretiske og empiriske bidrag til udviklingen af den distribuerede tilgang til sprog. Kongstanken i tilgangen er, at sproget indbefatter helkropslig, direkte koordination i og mellem individ og omverden (Cowley 2011). Tilgangen bygger dermed på en antirepræsentationalistisk antagelse, der samtidig udelukker, at sproget primært anskues som symbolsk processering, og at sproget er baseret på tegnrelationer alene. Tilgangen er inspireret af "nyere sprogvidenskabelige indsigter, særligt hentet fra den integrationelle lingvistiks (Harris 1981, 1998) kritik af det sprogsyn, der ligger til grund for størstedelen af det 20. århundredes lingvistiske teoretiseren" (Steffensen, dette nummer). Perspektivet afviser derfor, at verbale mønstre er repræsenteret inden $\mathrm{i}$ individet:

far from being a synchronic 'system', language is a mode of organization that functions by linking people with each other, external resources and cultural traditions. We concert speech, thinking, gesture and action in species-specific ways. (Cowley 2011: 2).

Dermed anskues sproget som en kollektiv, dialogisk, kognitiv og handlingsbaseret aktivitet. 
At sproget er distribueret og dermed rækker ud over det enkelte individs krop, er en antagelse, der stammer fra en interaktion mellem det integrerede sprogsyn (Harris 1981; Spurrett 2004) - der også anskuer sproget som socialt og dynamisk - og distribueret kognition (Cowley 2011; Giere 2004; Hutchins 1995a, 2014; Hollan et al. 2000). Linell $(2005,2007,2009,2015)$ understreger sprogets multitemporale aspekt forstået på den måde, at enhver artikulation går ud over den lokale situation, hvilket gør sproget til et grundlæggende dialogisk fænomen. Derudover fokuseres der i særdeleshed på sprog som helkropslige handlinger, hvilket gør det muligt at inkludere langt flere aspekter i den sproglige handling end et tegnbaseret sprogsystem. På den måde kan man som Cowley (2011) sige, at sprog altså ikke er et objekt i sig selv, men derimod et emergent fænomen.

Med distribueret sprog lægges der op til at studere sproget i den naturlige kontekst, det opstår i. Linell (2005) understreger, at det er en fejlslutning at antage, at vi kan anvende de samme metoder til studiet af social interaktion, som vi kan i analyse af tekstproduktioner. Misforståelsen, at sprogets ontologiske status er den samme i disse to kognitivt forskellige aktiviteter (at skrive med sproget og interagere med andre med sproget), stammer fra en prioritering af skriftsproget, som har bidraget til det, Linell (2005) kalder the written language bias (Linell 2005: 20). Denne skriftsproglige tradition har ikke kun fikseret teoretiske definitioner, den har også forplantet sig i de metoder, der er anvendt inden for interaktionsstudier (Kravchenko 2011).

Den distribuerede tilgang til sprog argumenterer altså mod den antagelse, at sprog kun er strukturer og tegnudveksling. Derfor placerer distribueret sprog sig i det hul inden for sprogforskningen, hvor der ikke er tilfredsstillende forklaringsmodeller for, hvordan kropslige og sociale aspekter medvirker til den sproglige kompleksitet i interaktion, der ikke lader sig indfange ved traditionelle lingvistiske metoder ( $\mathrm{fx}_{\mathrm{x}}$ strukturalistiske, men i det hele taget metoder, der undlader at integrere kognitive og sproglige dynamikker) (Pedersen 2015). Fx skal det nævnes, at der inden for interaktionsforskningen er konversationsanalytiske og diskursanalytiske tilgange, hvis intentioner har været at bevæge sig væk fra strukturelle og ordbaserede analyser af social interaktion. 
Disse tilgange har i stedet forsøgt at fokusere på de handlinger, der realiseres i fællesskab (Hutchby og Wooffitt 2011).

Særligt konversationsanalysen (engelsk: Conversation Analysis) (herefter CA), der er den førende tilgang til social interaktion, har fokuseret på sproget som handlingsbaseret og taget den empiriske udfordring op og har undersøgt den kropslige og adfærdsmæssige koordination, der udspiller sig i interaktionen. Metoden har undersøgt, hvordan den sociale orden opretholdes via forskellige systemiske funktioner som sekventielle turallokeringer (Sacks et al. 1974). CA vendte dermed den sociologiske modus operandi på hovedet ved at forholde sig induktivt til data og lade lokale mønstre i interaktionen danne udgangspunktet for videnskabelige hypoteser. Paradoksalt nok har CA-studierne bidraget til at gøre metoden så kategoritung - ved at opstille stadig flere kriterier for, hvordan den sociale orden opretholdes - at den over tid er blevet til en teori om samtalens natur. En teori, der antager, at sprogi-interaktion er et sekventielt turtagningssystem, der opretholder den sociale orden (Hutchby og Wooffitt 2011), står i skærende kontrast til det distribuerede perspektiv. Det distribuerede perspektiv antager, at interaktion er kognitiv og sproglig samhandling, hvorimod mainstream CA slet ikke forholder sig til kognitive processer i interaktionsanalysen:

cognitive and psychological phenomena are separate from social behaviour. They may be disclosed in social contexts, in that we can report our thoughts, verbalize our memories of events and articulate attitudes and beliefs; ultimately, though, they are not private phenomena. Finally, it seems uncontentious to assume that cognitive and psychological phenomena determine public social behaviour. (Hutchby og Wooffitt 2011: 217)

CA opretholder altså en skarp adskillelse mellem psykologiske, kognitive aktiviteter og social interaktion. Dermed reducerer CA kognition til interne mentale processer og undgår på den måde at forholde sig til fænomenet, da det i denne optik ikke kan observeres. Derudover er der stadig relativt få multimodale analyser af interaktion. I de tilfælde, hvor der faktisk udføres deciderede multimodale CA-analyser, bliver de non-verbale handlinger underlagt samme regler som dem, der er gældende for analyse af verbale artikulationer (Cowley 2011; 
Pedersen 2015; Steffensen 2013) ${ }^{1}$. Konsekvensen af sådanne interaktionsanalyser er et partielt sprogsyn, der prioriterer den sociale orden på bekostning af de biologiske og kognitive dynamikker, der spiller en rolle $\mathrm{i}$ interaktion.

I et distribueret perspektiv på sprog fremhæves sprogets økologiske karakter. At sproget betragtes som økologisk, er en konsekvens af dets forankring i en biologisk krop. Sproget er på en gang et socialt fænomen, der relaterer til den interpersonelle kontakt mellem mennesker, men det er samtidig en metabolisk aktivitet, der hænger sammen med kroppens biologiske mekanismer i forbindelse med lydproduktion, mikro-bevægelser og andre fysiske handlinger. Forklaringen af sproglige handlinger kræver derfor en udvidet referenceramme, der går ud over beskrivelser, der refererer til et sprogsystem eller mikrosociologiske normer og regler (Steffensen 2011: 205). Interaktion med andre er kendetegnet ved en aktivitet, hvor de sproglige artikulationer ses som en multimodal helhed af gestik, mimik, verbale artikulationer og andre kropslige handlinger, der alt sammen bidrager til interaktionen (Linell 2009; Cowley 2011; Steffensen 2013; Thibault 2011; Jensen 2014; Pedersen og Steffensen 2014; Pedersen 2010, 2012, 2015; Norris 2004).

Et væsentligt aspekt ved distribueret sprog er, at det primært er dynamisk og sekundært symbolsk (Cowley 2014). I den forbindelse bliver det relevant at diskutere, hvordan integrationen af flere tidsskalaer er central i et distribueret perspektiv på sprog. Det, en aktør siger, gør og udtrykker in situ, er betinget og begrænset af den historik, ekspertise og erfaring, han besidder (Pedersen og Steffensen 2014). Navigationsteamet på flådeskibet fra det forudgående eksempel er i stand til at handle funktionelt og effektivt, for det første fordi det har oparbejdet en ekspertise, der muliggør direkte meningsdannelse ud fra de lokale forhold, de enkelte teammedlemmer befinder sig i, og for det andet fordi de enkelte teammedlemmer sammen kan bero på hinandens kompetencer i realiseringen af et fælles mål. Samtidig er sproget dyna-

1 Der er en gryende tendens inden for etnografiskbaserede interaktionsstudier til at inddrage hele kroppen som semiotisk materiale, der også har en kognitiv karakter. Særligt Goodwin (1994, 2000, 2003, 2007), Streeck (2009) og Heath (2002) har forsøgt at linke kognition til den måde, hvorpå mennesker koordinerer deres handlinger bl.a. ved at orientere sig mod materielle artefakter, der er designet til at bidrage til en effektiv problemløsning. 
misk, forstået på den måde, at individer ikke kun er begrænset og styret af bagvedliggende mønstre og dynamikker, men også er i stand til at manipulere og skabe nye mønstre.

En konsekvens af et distribueret perspektiv på både kognition og sprog er, at distinktionen mellem de to bliver sløret. Når et kognitivt etnografisk studie kredser om spørgsmål som, hvordan en gruppe af individer beslutter, hvad der skal ske med en patient, er spørgsmålet på én og samme tid kognitivt og sprogligt forankret. En sådan undersøgelse er kognitiv i den forstand, at en gruppe individer skal løse en opgave (fx diagnosticere og dermed arbejde med hypoteser om kliniske og medicinske forhold), og den proces sker kontinuerligt i interaktionen. Samtidig indebærer en sådan undersøgelse, at der zoomes ind på den fleksible og adaptive adfærd, der får teamet til at koordinere dets handlinger, hvilket kan beskrives som en sproglig og kognitiv praksis. Dette vil blive illustreret med det distribuerede perspektiv på kognition og sprog i to efterfølgende analyseeksempler. Eksemplerne belyser de kognitive og sproglige handlinger, der bidrager til og begrænser diagnosticeringen af patienter på en akutafdeling i Danmark.

\section{KOGNITIV ETNOGRAFI OG KOGNITIV EVENT- ANALYSE}

Den analytisk-empiriske del præsenterer analyser af, hvordan diagnosticeringsprocesser i læge-patient-interaktioner er betinget af kropslig koordinering i og med omgivelserne. Med udgangspunkt i autentisk videomateriale har analyserne til formål at vise, hvorledes sproglige og kognitive processer udspiller sig i både normative dynamikker såvel som i synkroniserede interkropslige dynamikker. Et økologisk, distribueret perspektiv på sprog forkaster som sagt ideen om, at det er repræsentationer (altså det mentale billede, der indkodes i hjernen som resultatet af en perception), der er bindeleddet mellem perception eller tænkning - og artikulation. Dermed udviskes den skarpe grænse mellem det kognitive og det sproglige domæne, og fokus bliver på den koordination, der sker mellem mennesker og deres omgivelser.

Følgende analyseeksempler stammer fra et forskningsprojekt, der havde fokus på menneskelige fejl i diagnosticeringsprocesser på en 
akutmodtagelse på et dansk hospital (se Pedersen 2015). Projektet benytter kognitiv etnografi (Hutchins 1995a) til at undersøge autentiske situerede dynamikker i beslutningsprocesser og andre kognitive events. De primære data til analyse er videooptagelser af akutte diagnosticeringssituationer. Diagnosticering er i sin natur en kognitiv aktivitet: Det medicinske team skal afklare, hvilke symptomer patienten har, hvordan de relaterer sig til mulige diagnoser, og hvilken beslutning der følger disse iagttagelser. Det distribuerede perspektiv og DCS som det oplagte analyseobjekt muliggør derudover, at den overordnede koordinering $\mathrm{i}$ teamet integreres i analysen. Her tænkes fx på det forhold, at kognition kan være distribueret $\mathrm{i}$ tid, over sociale grupper og i de fysiske strukturer, som beskrevet tidligere. På den måde tages der højde for den kompleksitet, der opstår i en så kompliceret aktivitet som diagnosticering.

Analysen anvender primært Kognitiv Eventanalyse (engelsk: Cognitive Event Analysis) (herefter CEA) (Steffensen 2013) til undersøgelsen af kognitive events i akutmedicinske diagnosticeringssituationer. Metoden er særlig velegnet til mikroanalyser af kognitive events i interaktioner, da den retter fokus på korte tidsskalaer, hvor mange interkropslige dynamikker udspiller sig. Desuden retter metoden fokus på de resultater, et kognitivt system skaber, og de mulighedsbetingelser, der leder til resultaterne. Med et sådant fokus undgår man som analytiker at arbejde med en step-by-step-analyse af, hvad der sker i interaktionen, hvilket er tilfældet med fx CA's turn-by-turn-metodik. CEA's fokus rettes altså mod de betingelser og muligheder, et givent kognitivt system udnytter i dets forsøg på at skabe resultater og realisere et bestemt organisatorisk mål som fx diagnosticering. Sådanne betingelser defineres som omdrejningspunkter, ${ }^{2}$ der er afgørende for et givet udfald. I de følgende analyser uddybes de omdrejningspunkter, der får konsekvenser for løsningen af en kognitiv aktivitet, på en tidslinje. Desuden anvendes visuelle illustrationer $\mathrm{i}$ anonymiseret form.

Analyserne viser i sin helhed, hvordan kognitive og sproglige aspekter $i$ interaktionen gennemsyrer den akutte praksis, praktikere og patienter befinder sig i. I situationer, hvor mange aktiviteter skal håndteres på én gang ( $\mathrm{fx}$ anamnese, ${ }^{3}$ hypotesegenerering), forudsætter succesfuld

2 Den engelske term er "event pivot".

3 Patientens sygehistorie. 
opgaveløsning en høj grad af koordinering og fælles opmærksomhed. En sådan interaktion er dermed kognitiv og sproglig. CEA-analyserne undersøger således, hvordan praktikere på en akutmedicinsk afdeling håndterer sproglige og kognitive situationer på en måde, så problemer kan blive løst og sygdomme behandlet.

\section{ANALYSE: DIAGNOSTICERINGSPROCESSER I AKUT- MEDICIN}

\subsection{Afbrydelser, der fär det distribuerede kognitive system til at disintegrere}

Dette analyseeksempel fokuserer på en situation, der er karakteriseret af stigende stress og frustration, da en læge bliver overvældet af en række forventninger om at handle på divergerende måder på samme tid. Presset resulterer i en prioritering, der tilgodeser nogle af de involverede parter $i$ et DCS. I en efterfølgende analyse af et andet eksempel kontrasteres denne strategi med en funktionel strategi, hvor et team udnytter det fulde potentiale i et DCS.

I nærværende eksempel er en ældre dame netop ankommet med 112. Hun bløder rektalt, og hendes situation er akut og uafklaret: Blødningen fortsætter, hvilket er et alvorligt symptom, og ingen ved, hvorfor hun bløder. Til stede er en laborant, en sygeplejerske, en læge, en observatør og patienten. Lægen indleder en dialog med patienten for at få informationer, der kan lede til en tentativ diagnose. Hurtigt bliver han forstyrret af forskellige typer af afbrydelser. Nedenfor præsenteres et øjebliksbillede af situationen.

\section{FIGUR 1: OVERBLIK OVER SITUATIONEN}

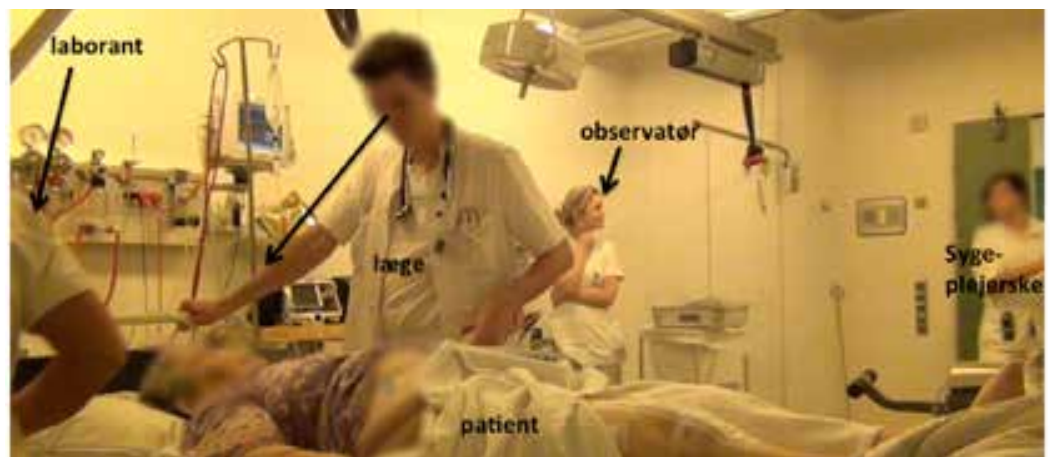


Samtalen mellem læge og patient er præget af lægens stigende frustration $\mathrm{i}$ takt med, at antallet af afbrydelser stiger. I nedenstående uddrag på 54 sekunder er der for eksempel syv afbrydelser. I analysen nedenfor rettes opmærksomheden mod de konsekvenser, de enkelte afbrydelser har for opretholdelsen af det DCS, som primært udgøres af lægen og patienten.

Afbrydelser, der andrer interaktionsflowet

1. 01:06:30, P: så blev jeg jo bange for jeg var alene hjemme ik ( $S$ kommer ind)

2. $01: 08: 40, \mathrm{~L}: \mathrm{ja}$

3. $01: 09: 10$, ps. $(0,5)$

4. 01:09:60, P: og så ringede jeg til (xxx) og de var ikke hjemme og så ringede jeg til (xxx) og de var $\underline{\text { heller }}$ ikke hjemme $=(S$ giver $L$ et papir $)$

5. $01: 13: 00, \mathrm{~L}:=$ tak

6. $01: 13: 40$, ps. $(1.1)$

7. $01: 14,50$, P: og vagtlægen havde lukket og det det hele [det (.) ramlede for mig (.) så tænkte jeg om jeg skulle ringe til

8. $01: 16: 80, \mathrm{~L}: \quad[N \AA$

9. $01: 20: 60$, ps. $(0.6)$

10. 01:21:20, P: S så slemt var det heller ikke vel

11. $01: 23: 10$, ps. $(2.1)$

12. $01: 25.20$, L: nej=

13. $01: 25: 90, \mathrm{P}:=$ =men $\mathrm{så}[$ her $(\operatorname{xxx}[\mathrm{x})$ jeg tror fredag, så skulle jeg på toilettet $i[k$

14. $01: 26: 40, \mathrm{~S}:$ [ var der en (xxx) på hende derovre

15. $01: 27: 70$, Tf [ring ring

16. $01: 32: 00$, Tf [ring ri[ng

17. $01: 32: 30, \mathrm{~L}:$

[ja

4 Forkortelser og markeringer i transskriptionen: P: patient, L: læge, S: sygeplejerske, Tf: telefon. Fed markering illustrerer timingen af de afbrydelser, der opstår undervejs i samtalen. 
18. 01:33:50, P: og så måtte jeg jo kalde på min datter som siger mor det er ikke (.) det er ikke [( $\mathrm{xxx})$ det er blod=

19. $01: 36: 40$, Tf

[ring

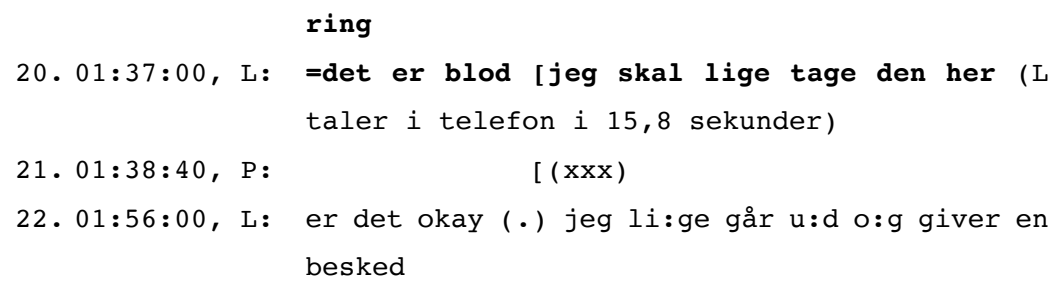

I denne sekvens bliver lægen afbrudt fem gange: to gange af sygeplejersken og tre gange af telefonen, der ringer. Derudover afbryder sygeplejersken lægen og patientens samtale, og endelig afbryder lægen patienten.

I figur 2 er afbrydelserne og timingen af hver afbrydelse markeret $\mathrm{i}$ forhold til den kognitive opgave, ligesom udviklingen i samtalen med patienten er beskrevet. Lægens blik, gestik og verbale artikulationer er analyseret som en sproglig helhed i relation til afbrydelserne. I de fortløbende analyser anvendes forbogstaverne i henholdsvis læge, patient og sygeplejerske som forkortelser for disse aktører. 


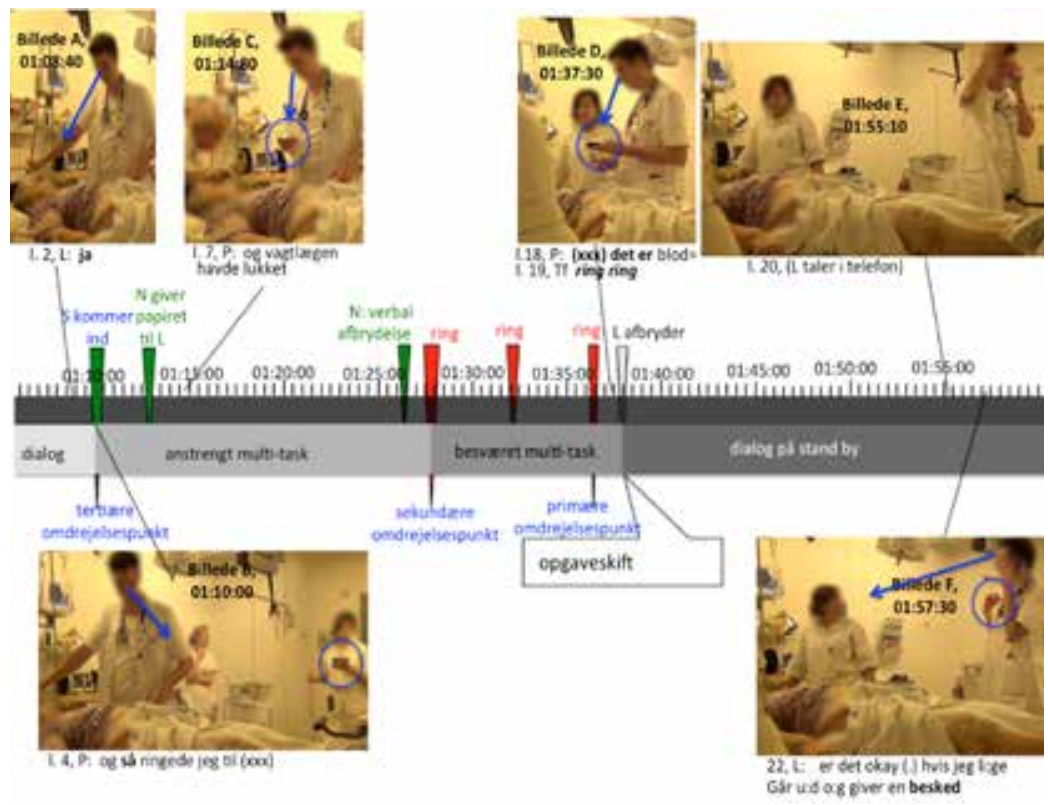

Som vist i figuren er dialogen indledningsvist karakteriseret ved sensitivitet og nærhed: Der er øjenkontakt og fælles fokus (se billede A og transskriptionen). I det øjeblik, S nærmer sig L med et papir i hånden, orienterer L sig mod dette (se billede B). Lægens fokusskift (fra P til papiret) skaber en dialogisk distance mellem $\mathrm{P}$ og $\mathrm{L}$ og samtidig en forstyrrelse i DCS. Efter L modtager papiret, kigger han på informationerne og forsøger samtidig at opretholde dialogen med P, om end han er begrænset af at skulle udføre to forskellige aktiviteter på samme tid: læsning af informationer, der leder til hypoteser om diagnose, og dialog med P (se billede C). L's sensitivitet er reduceret, og han synes i det hele taget begrænset af den interaktionelle kompleksitet: Der er ingen øjenkontakt, distancen til P forøges, og L's svar er forsinkede og minimalresponsen malplaceret, se nedenfor:

\footnotetext{
4. 01:09:60, P: og så ringede jeg til (xxx) og de var ikke hjemme og så ringede jeg til (xxx) og de var heller ikke hjemme= ( $\mathrm{S}$ giver L et papir)

5. $01: 13: 00, \mathrm{~L}:$ =tak

6. $01: 13: 40$, ps. (1.1)
} 
7. $01: 14,50, \mathrm{P}$ : og vagtlægen havde lukket og det det hele [det (.) ramlede for mig (.) så tænkte jeg om jeg skulle ringe til 112

8. $01: 16: 80, \mathrm{~L}: \quad[\mathrm{N \AA}$

9. $01: 20: 60$, ps. $(0.6)$

10. 01:21:20, P: s så slemt var det heller ikke vel

11. $01: 23: 10$, ps. $(2.1)$

12. $01: 25.20, \mathrm{~L}:$ nej=

L responderer ikke umiddelbart på P's ytringer, og der opstår lange pauser (se 1. 6, 9 og 11). Efter P har ytret, at det hele ramlede for hende, og hun ikke vidste, om hun skulle ringe 112, falder L's minimalrespons på aparte tidspunkter og artikuleres med en pludselig høj volumen: $N A$ (1. 8). Den sproglige koordinering er ude af sync og skaber et skift i det interaktionsflow, der oprindeligt var i samtalen. Dette ses i figur 2 som et skift fra dialog til anstrengt dialog og multitasking. Forklaringen er logisk: Informationerne på det papir, L har modtaget, indeholder resultater af de prøver, der er taget på $\mathrm{P}$ i ambulancen. Informationerne er vigtige, og de kan være afgørende for, hvad der skal ske med P. P's narrativ er ligesådan afgørende for at kunne sammenligne resultaterne med den oplevelse og situation, P var og er i. Udfordringen opstår, idet $\mathrm{L}$ ikke kan efterkomme begge aktiviteter (interagere med P og tolke resultaterne på papiret) optimalt på én gang alene.

Kort efter bliver L og P afbrudt af S, der taler 'hen over' P, da hun spørger laboranten efter nogle prøver. På dette tidspunkt er der ingen, der har direkte fokus på $\mathrm{P}$, som behandler afbrydelserne som sekundære. Igennem alle afbrydelserne fortsætter P med at berette om sin oplevelse og stopper ikke op til trods for de markante forstyrrelser. Umiddelbart efter S' afbrydelse ringer L's telefon (se figur 2). L retter øjeblikkeligt opmærksomheden mod telefonen (se billede D). På nuværende tidspunkt har L kigget i papiret i 17,70 sekunder og vender nu blikket mod telefonen, formentlig for at se, hvem der ringer. Telefonforstyrrelsen er markeret i figuren som det andet omdrejningspunkt $\mathrm{i}$ interaktionen, der ændrer flowet og leder til et decideret stresset og besværet interaktionsmode. L skal nu forholde sig (a) til P, der stadig fortæller om sin oplevelse til trods for, at telefonen ringer tre gange 
i træk, (b) til informationerne på papiret og sidst (c) til den kollega, der forsøger at komme i kontakt med ham over telefonen. Da telefonen ringer for tredje gang, er det ved at være sidste chance for at tage den, inden kaldet kategoriseres som ubesvaret. Hvis L ikke tager telefonen, prioriterer han den lokale situation med patienten (dialog) over dialogen med kollegaer. Det sidste ring bliver identificeret som det omdrejningspunkt, der leder til en omprioritering af de igangværende opgaver. Idet $\mathrm{P}$ ytrer det er blod= (1. 18), gentager $\mathrm{L}=\operatorname{det}$ er blod (1. 20), hvorefter lægen siger til $P$, at han bliver nødt til at besvare opkaldet. $\mathrm{P}$ responderer ikke, og $\mathrm{L}$ diskuterer med sin overordnede i telefonen $\mathrm{i}$ 15,8 sekunder, hvorefter han spørger $\mathrm{S}$ om tilladelse til at forlade stuen. $\mathrm{Da} L$ går, orienterer han sig ikke mod $\mathrm{P}$, der ligger i sengen og stirrer direkte ud i luften.

Da L tager telefonen, disintegrerer det DCS, han konstituerede sammen med P. Samtidig realiserer han et værdihierarki, der forfordeler P, og som umiddelbart kan betragtes som ignorerende adfærd overfor $\mathrm{P}$. Antageligvis opleves det også sådan af $\mathrm{P}$, der gentagne gange 'ikkeorienterer' sig mod afbrydelserne, der bør afbryde deres dialog. Sidst undlader hun at respondere eller orientere sig mod L, da han undskylder sin adfærd. Denne 'adfærd' er kendt fra andre læge-patient-studier: "all doctors and health systems purport to put patients first, but ample evidence shows that it often doesn't feel that way to patients. They regularly feel like cases rather than people, and what is important to patients is often different from what is important to doctors" (Smith 2003: 1433). Derudover bidrager et distribueret perspektiv på interaktion med et fokus på situationens transsituationelle og dialogiske aspekter: "humans are always interdependent with others, although the degree and kinds of interdependencies will of course vary with individuals, cultures and situations" (Linell 2009: 13). Enhver situation relaterer til andre situationer; situationer i fortiden og fremtiden. Fortiden og kulturen på afdelingen udstyrer tilsyneladende L med en forventning om, hvordan han skal respondere på opkaldet, og konsekvensen af hans valg kan rettes mod fremtiden. L's stressede adfærd kan ses som en konsekvens af forsøget på at realisere flere aktiviteter på én gang. Dette kan være en plausibel forklaring på, at L ikke umiddelbart tager telefonen, før det næsten er for sent. Paradoksalt nok 
bliver denne strategi et udtryk for manglende sensitivitet $i$ alle henseender. Idet L påtager sig at løse alle opgaver selv, bliver den kognitive aktivitet så kompleks og krævende, at DCS til sidst disintegrerer. L agerer kognitiv hovedperson i det lokale DCS, og han udnytter ikke potentialet for at bearbejde og udvide dets grænser, så andre aktører også får en central, hjælpende eller understøttende rolle og dermed kognitiv funktion i situationen.

Dette illustreres bedst i et modeksempel. Følgende uddrag viser et andet teams håndtering af en tilsvarende telefonafbrydelse:

\section{Et DCS' funktionelle håndtering af afbrydelser}

8. $00: 14: 60, \mathrm{~L}: \mathrm{mm}$

9. $00: 15: 00$, Tf ri[ng ring

10. 00:15:70, P: [der [s:ynes jeg at (.) der nogen gange er sådan

11. $00: 16: 10, \mathrm{~L}:$ [hov ( $\mathrm{S}$ tager telefonen $i$ hånden)

12. $00: 17: 80$, ps. (1.3)

13. 00:19:10, P: m[en det har jeg haft (hoster)

14. $00: 19: 20$, Tf [ring ring

15. $00: 21: 20$, ps. $(0,5)$

16. 00:21:70, P: d [et har jeg haft før (.) (xxx) føler jeg at (.) det lige slår

17. 00:21:80, S: [det er (S's navn) (.) det er bare lige (L's navn) telefon

I modeksemplet understreges det, hvordan $\mathrm{S}$ anticiperer konsekvenserne ved L's latente handlingsmønster. Da L's telefon ringer midt i en anamneseproces, rækker S ud efter L's telefon, idet han retter blikket mod sin lomme, hvori telefonen ligger: 


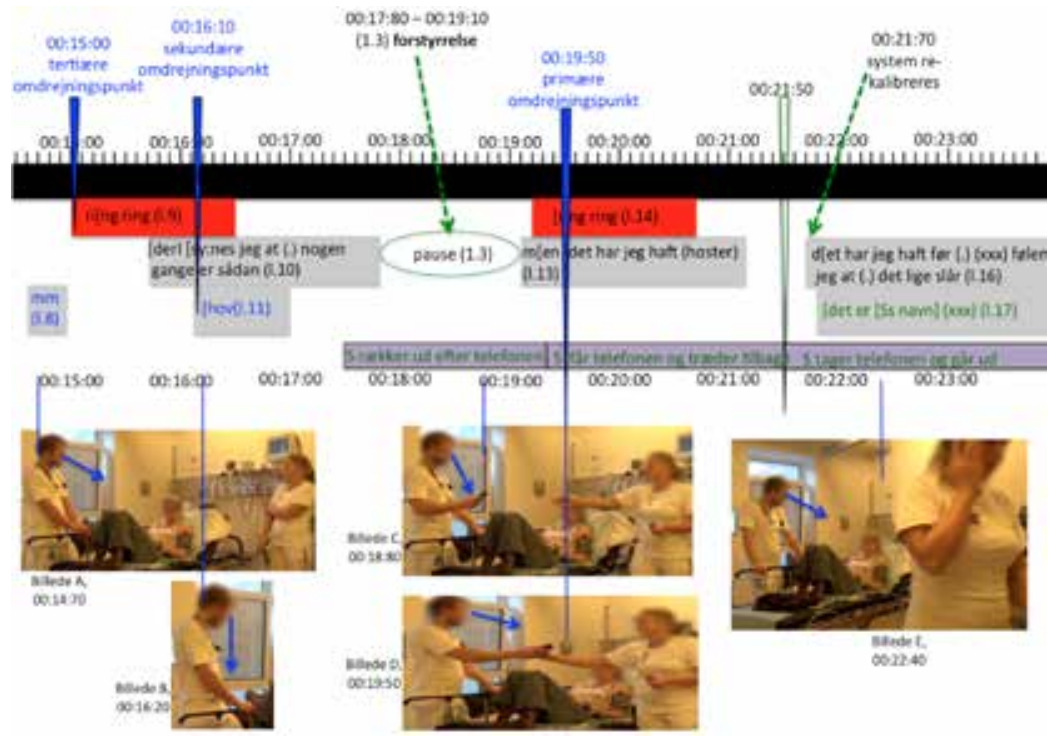

Som i det første eksempel opfatter L også opkaldet som relevant (se billede B og C). S er løst koblet til det DCS, L og P konstituerer (se billede $\mathrm{A}$ ). Idet $\mathrm{S}$ rækker ud efter telefonen, inden $\mathrm{L}$ når at tage den, skaber hun en potentiel mulighed for, at $\mathrm{P}$ og $\mathrm{L}$ kan opretholde deres DCS og fortsætte samtalen upåvirket af afbrydelsen. Idet L giver $\mathrm{S}$ telefonen, retter han blikket tilbage mod P (se billede D). P fortsætter sin narrativ, og $\mathrm{S}$ forlader stuen (se billede $\mathrm{E}$ ) for at forstyrre mindst muligt. Der er en minimal forstyrrelse på 1,3 sekunder (se figur 3), mens L orienterer sig mod sin telefon og tager den op af lommen. Da $\mathrm{S}$ har taget telefonen, genetablerer L dialogen med P, og DCS er hurtigt og effektivt genskabt (se figur 3). Idet $S$ håndterer denne opgave, skaber hun et indlejret opgavehierarki, der muliggør, at teamet som helhed kan håndtere flere kognitive aktiviteter samtidigt uden at blive stresset eller påvirke de interpersonelle relationer negativt. Dette lykkes ved teamets koordinerende adfærd i ord, bevægelse, blik og S' anticipatoriske adfærd.

Tilsammen viser de to analyseeksempler, hvordan (a) sprog og kognition sammensmelter i professionelle interaktioner, og (b) hvordan grænserne $i$ et DCS afhænger af den kognitive og sproglige koordinering, der pågår. I det første eksempel disintegrerer DCS på grund 
af kognitiv overbelastning hos L, hvilket igen leder til et skift $i$ interaktionsflowet, der påvirker opgaveløsningen negativt. I det sidste eksempel ser vi, hvordan teamets koordinerende adfærd muliggør, at organisationens behov om øjeblikkelig reaktion på afbrydelser opfyldes, samtidig med at $\mathrm{P}$ bliver prioriteret.

\subsection{Gestik som kognitiv ressource i symptombeskrivelse}

Det sidste eksempel involverer en dialog mellem en mandlig læge og en kvindelig, ældre patient, der er ankommet på akutafdelingen grundet stærke mavesmerter tidligere på dagen. Hendes sygehistorie er kompliceret, og hun er diagnosticeret med en række kroniske sygdomme. Opgaven er derfor at få defineret de specifikke symptomer, hun har, så lægen kan se en sammenhæng mellem lokale smerter og kroniske sygdomme eller nye akut opståede sygdomstilfælde. Nedenfor visualiseres situationen af lægen og patienten.

FIGUR 4: OVERBLIK OVER SITUATIONEN

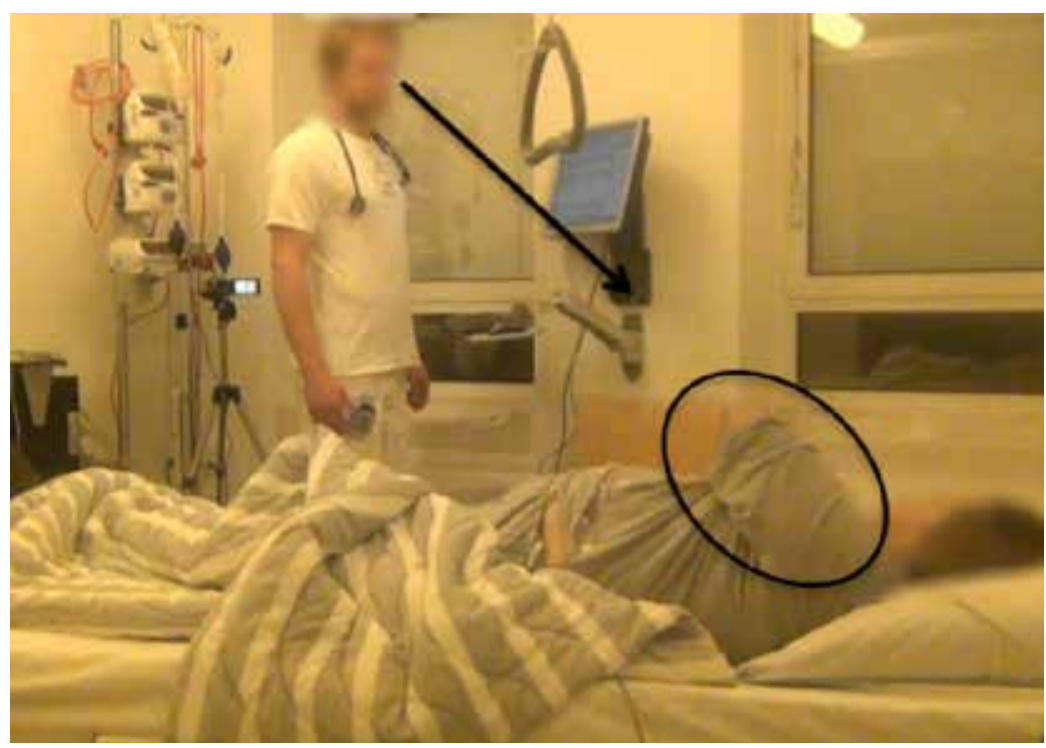


Lægen spørger indledningsvist til patientens symptomer og beder hende uddybe, hvor det gør ondt lige nu og siden forløbet startede. Følgende dialog udspiller sig mellem dem.

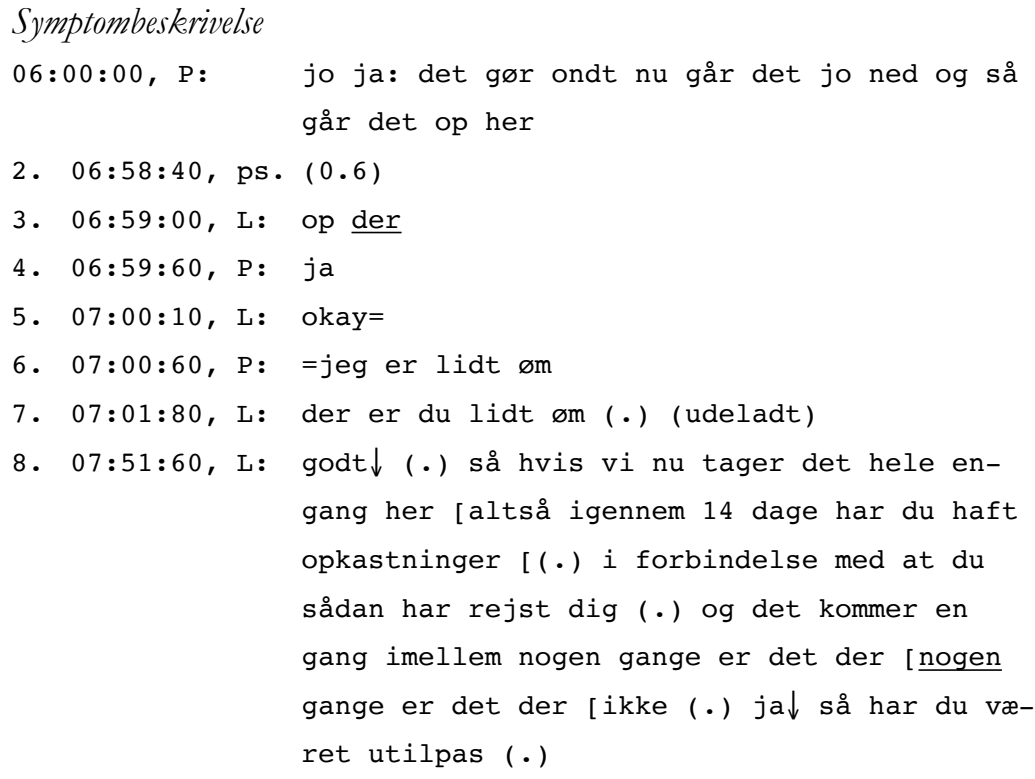

[ja

13. 08:07:10, L: og så samtidig så er det blevet lidt værre med din åndenød som du [ellers har haft igennem mange år

14. $08: 09: 50, P:$ 


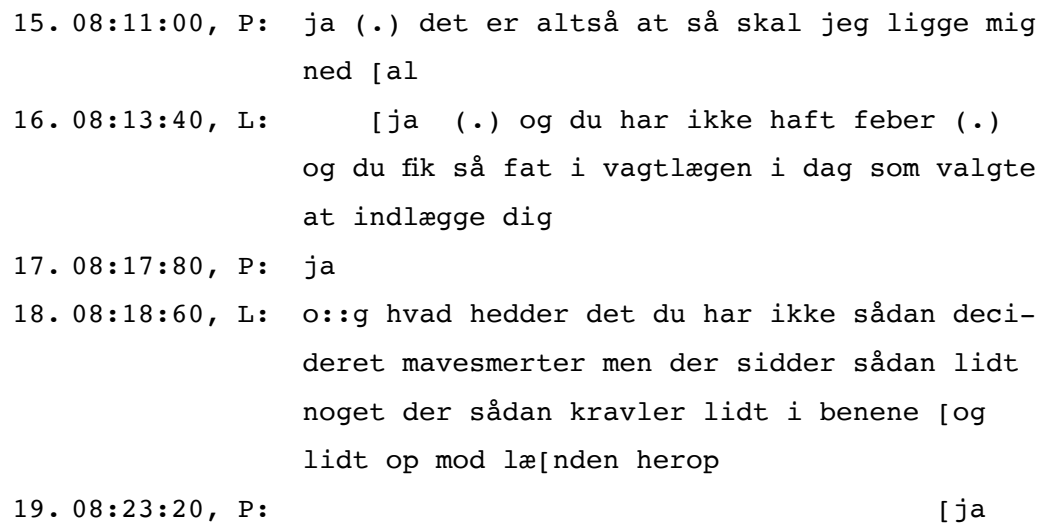

[ ja herop

Efter $\mathrm{L}$ har bedt $\mathrm{P}$ om at lokalisere og beskrive sine smerter, bruger $\mathrm{P}$ sin gestik til at vise området og bevægelsen for smerten i sin højre side (se billede A nedenfor).

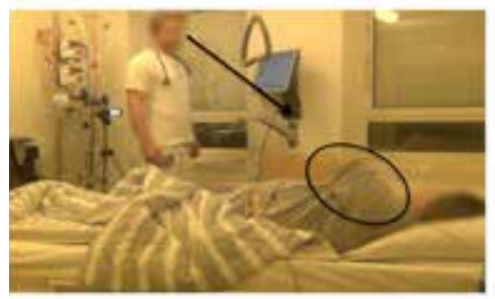

siliede A ob:stoo it. in edrdet oo het

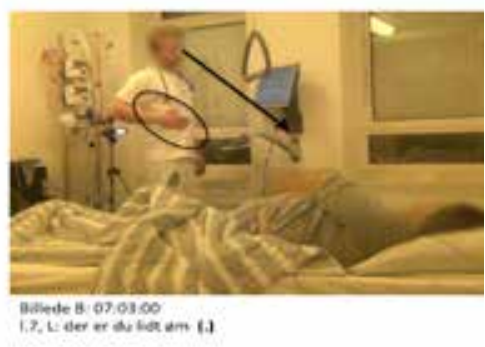

Markeringer med fed $i$ transskriptionen under billederne symboliserer den verbale artikulation, der sker, $i$ det ojeblik. billedet er taget.

P og L konstituerer et DCS, hvor fælles meningsdannelse realiseres, idet de koordinerer deres interkropslige handlinger in situ. L følger P's bevægelse og udtrykker overraskelse over patientens lokalisering af smerter: op der (1. 3). Fire sekunder efter P har lokaliseret sine smerter, rører L sin egen højre side svarende til P's forudgående handling (se billede B). Deres selvberøringer fungerer som et gensidigt visuelt display, der muliggør, at de kan korrigere lokaliseringen i forhold til hinandens bevægelser. I stedet for udelukkende at bero på verbalsproglige kompetencer anven- 
der L en multimodal strategi, der gør hans krop til en vigtig kognitiv ressource, der fungerer som et væsentligt aspekt i den kooperationelle dialog (Goodwin 2013) mellem L og P. På den måde bruger de ikke kun gestikken som et middel til informationsbehandling eller udtryk; meningen fremkommer derimod i den kontinuerlige proces med at koordinere deres adfærd, en observation som også Streeck (2010) har gjort:

Rather than perceiving gestures as part of language, an ecological perspective is proposed [...] This broader account of gesture requires a different conception of the human body than is commonly presupposed by researchers of "non-verbal communication": a model of the body not as an instrument of expression, but as a skilled (knowing) inhabitant of worlds. (Streeck 2010: 223)

Efter L og P har skitseret en række symptomer, opsummerer L P's narrativ. L's gestik er rig og fremtrædende i opsummeringen, og resultatet er en effektiv, klar og dialogisk formidling, som P forholder sig direkte til og korrigerer undervejs, hvis nødvendigt. Nedenfor præsenteres opsummeringen $\mathrm{i}$ et galleri med fokus på gestikken $\mathrm{i}$ interaktionen.

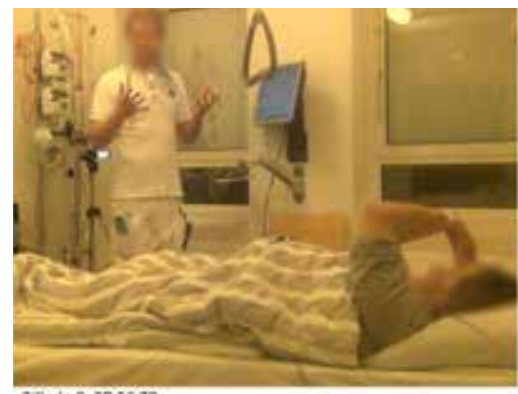

Bilede C: 0756:70

18, L: at du sidas har rejat dis

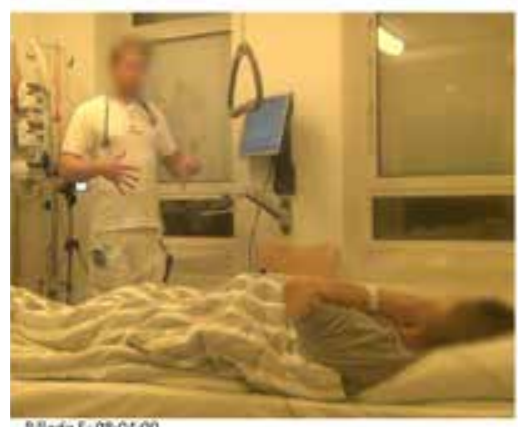

Bilede E; 08:04:00

111. L har haft tiltagende maviomtang

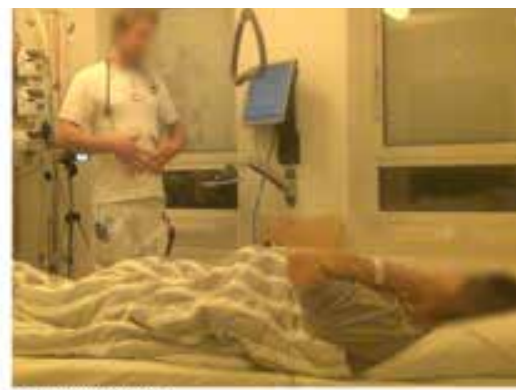

Bilede 0;08:03:50

1.11, L har hat tilatende moveomfant

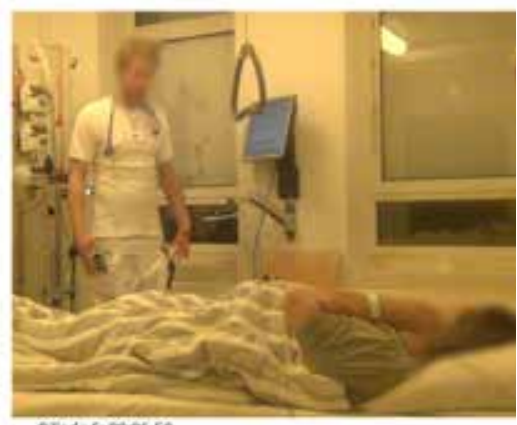

Blede f: cos:0s:50

111. L: og dine beo or ogla thanvet op 


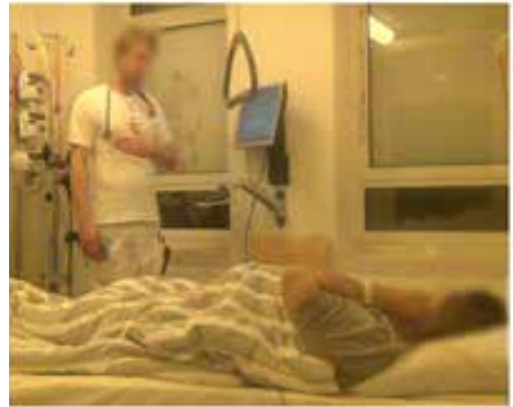

Bllede $\mathrm{G}: 08.08: 90$

1.13, Li lidt varme med din inderod

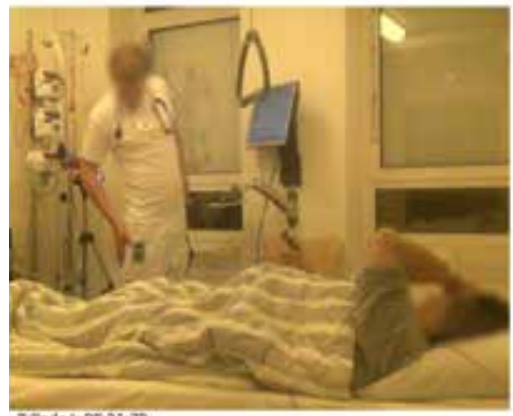

Biede 0.052100

18. Linoget der sidan kerwler lidt i benene

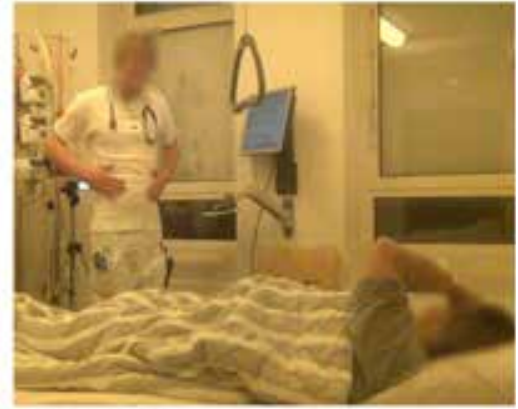

Bilede HE: 08:20:20

148. L: iu har ibse sidan decideret maveimerter

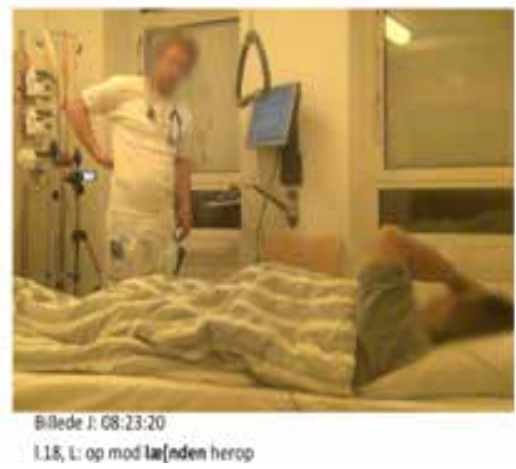

På grund af L's multimodale handlinger kan P forholde sig til en konkret narrativ; den semantiske betydning af opsummeringen, alt imens hun også kan relatere L's gestik til symptomers lokalisering på sin egen krop. Dette er en funktionel og effektiv strategi, der skaber klarhed og forbinder et smerteområde til et visuelt genkendeligt felt fremfor til en medicinsk fagkategori. Det er ofte tilfældet, at den gennemsnitlige patient ikke er klar over den specifikke grænse mellem fx mave- og brystregion eller mellem lænd og hofte. L's gestik fungerer derfor som en form for kropslig indeksikalitet (billede $\mathrm{H}$ og $\mathrm{G}$ ), der frembringer en specifik betydning, og som gør, at P's hukommelse faciliteres af en multimodal narrativ. L og P er i stand til at samhandle og tilpasse sig de skift, der sker i DCS, fx da L tilpasser sin perception af P's lokalisering af smerter, mens han bevæger sin egen hånd. 
Brugen af gestik i denne dialog er særdeles funktionel og effektiv, da den fungerer sammen med en narrativ og muliggør, at P's hukommelse frembringes af flere interaktionelle ressourcer i DCS. Dette er helt i overensstemmelse med resultater fra andre analyser:

interaction [...] is never 'about' one level of context [...] Rather, it is simultaneously 'about' all of the scales of embodied context the participants bring to bear during the interaction. Embodied action (including speech) always contributes to the sustaining of multiple nested contexts at once. (Streeck og Jordan 2009: 454).

Konkluderende kan det understreges, at et distribueret perspektiv på diagnosticering bidrager til en udvidet forståelse af, hvad, hvor og hvordan kognition frembringer/frembringes, og hvorledes interaktionen henholdsvis opretholdes, koordineres og bryder sammen.

\section{DISKUSSION: IMPLIKATIONER FOR TEORI OG PRAK- SIS}

Specifikt understreger analyserne, (a) at praktikere håndterer uforudsigelige situationer ved at reducere sensitiviteten i DCS og forsøge at koordinere flere aktiviteter individuelt, (b) at et teams koordinerende adfærd muliggør, at flere kognitive opgaver kan realiseres på samme tid, og $(c)$ at en rig og interkropsligt forankret gestik bidrager til en fælles og koncis forståelse mellem flere parter. Analyserne hæfter sig ved, at flere aspekter er medvirkende til et (dys)funktionelt resultat, og resultatet afhænger i høj grad af den enkelte og det enkelte teams evne til at koordinere forventninger og situationelle forhold ( $\mathrm{fx}$ afbrydelser). Ved at betragte sprog og kognition som distribuerede aktiviteter udvides analyseobjektet fra enkelte individer til et DCS, der omfatter koordination mellem individer, deres omgivelser ( $\mathrm{f} x$ materielle artefakter og strukturer som u- eller nedskrevne regler for adfærd på en hospitalsstue, computerens placering i forhold til patienten etc.) samt tidsdimensioner, der rækker ud over den lokale situation. I disse analyser har fokus været på den sproglige og kognitive dimension i relationen mellem personer og fysiske strukturer og artefakter, som $\mathrm{fx}$ telefonen i de første to analyseeksempler. Det distribuerede perspektiv bidrager 
således til en nuanceret forståelse af, hvad sprog i interaktion er, og hvordan det undersøges empirisk. Konsekvensen af det distribuerede perspektiv afspejles ikke kun på et teoretisk plan. Metodisk er der brug for en analysemetodik som kognitiv etnografi og herunder CEA, der indfanger sprog og kognition som kropslige handlinger og fokuserer på den synkronicitet og timing af den samkoordinerende handling, der sker i DCS (Hutchins 1995a). Kombineret med kognitiv etnografi giver CEA altså mulighed for at tilgå de hurtige og langsomme tidsskaler, der gennemsyrer lokale situationer.

Ydermere kan et distribueret perspektiv have praktiske implikationer for, hvordan man organiserer og designer omgivelser, hvor der skal træffes beslutninger og løses opgaver, samt for hvordan man uddanner praktikere. Analyserne af afbrydelsessituationerne viser bl.a., hvad styrken af at arbejde i teams kan være, hvis teammedlemmerne får koordineret og udnyttet teamets kompetencer.

Trods analysernes resultater kan der godt optegnes generelle anvisninger for, hvordan man i en uddannelsesmæssig og læringsmæssig sammenhæng med fordel kan tænke diagnosticeringssituationer ud fra tanken om DCS. Styrken ved at fokusere på et DCS er, at der fokuseres på, hvordan systemet bidrager til resultater fremfor at isolere fokus til det enkelte individs kapacitet og kompetencer. Fx har man på den afdeling, hvor data er indsamlet, initieret en uddannelsespraksis som led i praktikernes hverdag, der består $\mathrm{i}$ at videooptage egen praksis og evaluere ikke blot, hvad der bliver sagt, men hvad der bliver gjort i det overordnede DCS. Desuden er praktikerne blevet præsenteret for analyser baseret på distribueret sprog og distribueret kognition, og de er blevet opfordret til at genoverveje udfordringer, muligheder og ekspertise ud fra disse perspektiver. Konkret kan nævnes, at de fx arbejder med gestik, stemmeføring, fysisk kontakt og koordinering. Det afgørende er, at koordineringen af sådanne interaktionelle aspekter sker i forhold til det specifikke DCS, de befinder sig i. Desuden er der på afdelingen sat fokus på generelle faktorer, der hæmmer en optimal og dialogisk opgaveløsning, og som ofte rækker ud over den enkeltes ansvarsområde, men som kan håndteres af teamet som helhed ( $\mathrm{fx}$ afbrydelser). Mest afgørende er dog, at de arbejder læringsorienteret ved at observere og udvikle praksis på baggrund af reelle, observerede problemstillinger, som praktikerne ikke umiddelbart er bevidste om 
in situ. Førhen blev uddannelsesprogrammer designet med udgangspunkt i standardiserede kommunikationstest, hvis øvelser praktikerne allerede mestrer tilfredsstillende. Med videoobservation derimod kan man fokusere intersubjektivt på de problemer, der - oplevede eller ej in situ - identificeres, og dermed reducere læringsfokus til det, der ikke fungerer. Et konkret resultat baseret på denne arbejdsmetode er, at det materielle og praktiske design af akutstuerne løbende evalueres og omorganiseres for at skabe de bedste betingelser for et funktionelt og effektivt DCS. Forståelsen af kognition og sprog som distribueret er vigtig i udarbejdelsen af disse arbejdsmiljøer, da perspektiverne giver indsigt i den kompleksitet, arbejdsprocesserne omfatter (Nemeth et al. 2004). Inden for menneske-computer-interaktionsfeltet (Human Computer Interaction) drager kognitionsforskeren David Kirsh en lignende parallel: "Once we understand the complex coordination [...] we will begin to reach new hights in design, and create a cognitively better world of physical-digital coordination" (Kirsh 2013: 28). Sagt på en anden måde opfordrer et distribueret perspektiv til, at man tænker i arbejdsmiljøer fremfor arbejdsopgaver.

I sin helhed viser artiklen fordelene ved, at interaktionsstudier tilpasser sine metoder i overensstemmelse med antagelser om sprog og kognition som distribuerede aktiviteter. Konsekvenserne af, at man tilpasser sine metoder, rækker ind i den videnskabelige praksis såvel som den organisatoriske praksis, idet nye indsigter og resultater bringes frem i lyset.

Sarah Bro Trasmundi

sarbro@sdu.dk

Syddansk Universitet

Center for Human Interactivity 


\section{LITTERATUR}

Anderson, M.L., M.J. Richardson og A. Chemero. 2012. Eroding the boundaries of cognition: implications of embodiment. Topics in Cognitive Science 4(4). 717-730.

Boden, M.A. 2006. Mind as machine: a history of cognitive science, Volume $1 \& 2$. Oxford: Oxford University Press.

Carman, T. 2008. Merleau-Ponty. New York: Routledge.

Cowley, S.J. 2007. Cognitive dynamics and distributed language. Language Sciences 29(5). 575-583.

Cowley, S.J. 2009. Distributed language and dynamics. Pragmatics \& Cognition 17(3). 495-507.

Cowley, S.J. 2010. Beyond symbols: interaction and the enslavement principle. J. Streeck (red.), New adventures in language and interaction. 47-70. Amsterdam: John Benjamins.

Cowley, S. J. 2011. Distributed language. Amsterdam: John Benjamins.

Cowley, S.J. 2014. Human language and sensorimotor contingency. J.M. Bishop og A.O. Martin (red.), Contemporary sensorimotor theory. 235-255. Dordrecht: Springer.

Gibson, J.J. 1979/86. The ecological approach to visual perception. Hillsdale, NJ: Lawrence Erlbaum Associates.

Giere, R.N. 2004. The problem of agency in scientific distributed cognitive systems. Journal of Cognition and Culture 4(3/4). 759-774.

Goodwin, C. 1994. Professional vision. American Anthropologist 96(3). 606-633.

Goodwin, C. 2000. Practices of color classification. Mind, culture and activity 7(1-2). 19-36.

Goodwin, C. 2003. The body in action. J. Coupland og R. Gwyn (red.), Discourse, the body and identity. 19-42. New York: Palgrave/Macmillan.

Goodwin, C. 2007. Language, culture, social organization and the material world: why a five field approach is necessary. Teaching Anthropology: SACC Notes 13(2). 5-9.

Goodwin, C. 2013. The co-operative, transformative organization of human action and knowledge. Pragmatics 46. 8-23.

Harris, R. 1981. The language myth. London: Duckworth.

Heath, C. 2002. Demonstrative suffering: the gestural (re)embodiment of symptoms. Journal of Communication 52. 597-617.

Hollan, J., E. Hutchins og D. Kirsch. 2000. Distributed cognition: Toward a new foundation for human-computer interaction. J. Carroll (red.), Human-computer interaction in the new millennium. 75-94. New York: Addison-Wesley.

Hutchby, I. og Wooffitt, R. 2011. Conversation analysis. Cambridge: Polity Press.

Hutchins, E. 1995a. Cognition in the wild. Cambridge MA: MIT Press.

Hutchins, E. 1995b. How a cockpit manages its speed. Cognitive Science 19. 265-288.

Hutchins, E. 2014. The cultural ecosystem of human cognition. Philosophical Psychology 27. 34-49. 
Hutchins, E.L. og T. Klausen. 1996. Distributed cognition in an airline cockpit. Y. Engeström og D.Middleton(red.), Cognitionandcommunicationatwork.15-34.NewYork:CambridgeUniversity Press.

Hutchins, E.L. og L. Palen. 1997. Constructing meaning from space, gesture, and speech. L.B. Resneck, R. Saljo, C. Pontecorvo og B. Burge (red.), Tools, and reasoning: Essays in situated cognition. 23-40. Wien: Springer-Verlag.

Jensen, T.W. 2014. New perspectives on language, cognition, and values. Journal of Multicultural Discourses 9(1). 71-78.

Kirsh, D. 2013. Embodied cognition and the magical future of interaction design. ACM Transactions on Computer-Human Interaction 20(1). 1-30.

Kravchenko, A.V. 2011. The experimental basis of speech and writing. S.J. Cowley (red.), Distributed language. 33-55. Amsterdam: John Benjamins.

Lakoff, G. \& M. Johnson. 1999. Philosophy in the flesh. The embodied mind and its challenges to western thought. Basic Books: New York.

Linell, P. 2005. The written language bias in linguistics: Its nature, origins and transformations. London: Routledge.

Linell, P. 2007. Dialogicality in languages minds and brains: is there a convergence between dialogism and neuro-biology? Language Sciences 29. 605-620.

Linell, P. 2009. Rethinking language, mind, and world dialogically: Interactional and contextual theories of human sense-making. Charlotte, NC: Information Age Publishing.

Linell, P. 2015. Dialogism and the distributed language approach: a rejoinder to Steffensen. Language Sciences 50. 120-126.

Love, N. 2004. Cognition and the language myth. Language Sciences 26. 525-544.

Nemeth, C.P., R.I. Cook, M. O’Connor og P.A. Klock. 2004. Using cognitive artifacts to understand distributed cognition. Systems, Man and Cybernetics, Part A: Systems and Humans, IEEE Transactions 34(6). 726-735.

Newell, A., C. Shaw og H.A. Simon. 1958. Elements of a theory of human problem-solving. Psychological Review 65. 151-166.

Norris, S. 2004. Analyzing multimodal interaction: a methodological framework. New York: Routledge.

Pedersen, S.B. 2010. Towards dialogical health care practices: human errors as a result of cultural affordances. S.J. Cowley, S.V. Steffensen, J.C. Major og A. Dinis (red.), Signifying bodies: Biosemiosis, interaction and health. 245-276. Braga, Portugal: Portuguese Catholic University Press.

Pedersen, S.B. 2012. Interactivity in health care: bodies, values and dynamics. Language Sciences 34(5). 532-542.

Pedersen, S.B. 2015. The cognitive ecology of buman errors in emergency medicine: an interactivity-based approach. Ph.d.-afhandling. Syddansk Universitet. 
Pedersen, S.B. og S.V. Steffensen. 2014. Temporal dynamics in medical visual systems. Cybernetics \& Human Knowing 21. 143-157.

Ross, D. 2004. Metalinguistic signalling for coordination amongst social agents. Language Sciences 26(6). 621-642.

Sacks, H., E.A. Schegloff og G. Jefferson. 1974. A simplest systematics for the organization of turn-taking for conversation. Language 50(4). 696-735.

Smith, R. 2003. Thoughts for new medical students at a new medical school. BMJ 327(7429). 1430-1433.

Spurrett, D. 2004. Distributed cognition and integrational linguistics. Language Sciences 26 (6). $497-$ 501.

Steffensen, S.V. 2011. Beyond mind: an extended ecology of languaging. S.J. Cowley (red.), Distributed language. 185-210. Amsterdam: John Benjamins.

Steffensen, S.V. 2012. Care and conversing in dialogical systems. Language Sciences 34. 513-531.

Steffensen, S.V. 2013. Human interactivity: problem-solving, solution-probing, and verbal patterns in the wild. S.J. Cowley og F. Vallee-Tourangeau (red.), Cognition beyond the brain: Computation, interactivity and buman artifice. 195-221. Dordrecht: Springer.

Steffensen, S.V. 2015. Distributed language and dialogism: notes on non-locality, sense-making and interactivity. Language Sciences 50. 105-119.

Steffensen, S.V. 2016. Sprogvidenskabens kognitive spørgsmål: En introduktion til den distribuerede sprogtilgang. NyS 50.13-54.

Steffensen, S.V. og S.J. Cowley. 2010. Signifying bodies and health: a non-local aftermath. S.J. Cowley, S.V. Steffensen, J.C. Major og A. Dinis (red.), Signifying bodies: Biosemiosis, interaction and health. 331-356. Braga: Portuguese Catholic University Press.

Streeck, J. 2009. Gesturecraft: the manu-facture of meaning. Amsterdam: Benjamins.

Streeck, J. 2010. New adventures in language and interaction. Amsterdam: Benjamins.

Streeck, J. og S.J. Jordan. 2009. Communication as a dynamical system: the importance of timescales and nested contexts. Communication Theory 19. 445-464.

Thibault, P.J. 2011. First-order languaging dynamics and second-order language: the distributed language view. Ecological Psychology 23 (3). 1-36.

Varela, F.J., E. Thompson og E. Rosch. 1991. The embodied mind. Cognitive science and human experience. Cambridge, MA: MIT Press. 